\title{
ANALISIS MOTIVASI BELAJAR SISWA KELAS II SEKOLAH DASAR NEGERI
}

\author{
Dwi Utari ${ }^{1}$, Elpri Darta Putra ${ }^{1}$ \\ ${ }^{1}$ Universitas Islam Riau, Indonesia \\ *Corresponding Address: dwiutari@ student.uir.ac.id
}

Naskah diterima: 9 Agustus 2021| Disetujui: 2 September 2021| Diterbitkan: 3 September 2021

\begin{abstract}
This study aims to describe the student's learning motivation in class II SDN 016 Kopah Village. The type of this research is descriptive qualitative research. The subjects of this study were second grade teachers and all second grade students at SDN 016 Kopah Village. Data collection techniques used are interviews, observation and documentation. The data analysis technique used the Milles and Huberman model with stages, data reduction, data presentation, and drawing conclusions. The results of the study indicate that the teacher always provides learning motivation to students during the learning process. given by the teacher, namely, 1) Praise Motivation, 2) rewards, 3) and the use of interesting activities during the learning process. There are some students who are included in intrinsic motivation. Intrinsic motivation factors, namely, 1) the desire and desire to succeed, 2) the drive and need in learning, 3) the expectations and ideals, and 4) the appreciation in learning. The criteria for students who have extrinsic motivation are students who always need encouragement, praise and appreciation from the teacher. The researcher make interpretation of this study that the learning motivation of second grade students of State Elementary Schools can be said to be good, seen from 13 students who have many intrinsic motivations in second grade students of SDN 016 Kopah Village.
\end{abstract}

Keywords: Learning Motivation, Students, Elementary School

\begin{abstract}
Abstrak: Penelitian ini mempunyai tujuan untuk menggambarkan motivasi belajar siswa di kelas II SDN 016 Desa Kopah. Jenis penelitian ini adalah kualitatif deskriptif. Subjek penelitian ini adalah guru kelas II serta seluruh siswa kelas II di SDN 016 Desa Kopah. Teknik pengumpulan data yang digunakan adalah wawancara, observasi, dan dokumentasi. Teknik analisis data menggunakan model Milles and Huberman dengan tahapan, reduksi data, penyajian data, dan penarikan kesimpulan. Hasil penelitian menunjukkan bahwa guru selalu memberikan motivasi belajar kepada siswa selama proses pembelajaran. Motivasi yang diberikan guru, yaitu 1) memberikan pujian, 2) penghargaan, 3) serta menggunakan kegiatan menarik selama proses pembelajaran. Terdapat beberapa siswa yang termasuk kedalam motivasi instrinsik. Faktor motivasi instrinsik, yaitu 1) adanya hasrat dan keinginan berhasil, 2) adanya dorongan dan kebutuhan dalam belajar, 3) adanya harapan dan cita-cita, dan 4) adanya penghargaan dalam belajar. Kriteria siswa yang memiliki motivasi ekstrinsik adalah siswa yang masih selalu membutuhkan dorongan, pujian, dan penghargaan dari guru. Kesimpulan dari penelitian ini adalah, motivasi belajar siswa kelas II Sekolah Dasar Negeri sudah dapat dikatakan baik dilihat dari 13 siswa sudah banyak yang memiliki motivasi instrinsik di dalam diri siswa kelas II SDN 016 Desa Kopah.
\end{abstract}

Kata kunci : Motivasi belajar, Siswa, Sekolah Dasar 


\section{PENDAHULUAN}

Pendidikan merupakan salah satu kunci dalam memajukan suatu bangsa dan negara. Pendidikan mempunyai peranan yang sangat penting untuk kemajuan suatu bangsa. Pendidikan sangat penting dalam menetapkan karakter pribadi seorang manusia. Manusia dapat menjadi pribadi yang baik atau buruk karena faktor pendidikan dan lingkungan, bukan karena tabiat aslinya. Manusia pada dasarnya adalah makhluk yang terus tumbuh dan berkembang baik fisik maupun mentalnya (Nugroho, 2020).

Pembelajaran adalah kegiatan pokok dalam proses pendidikan, karena melalui kegiatan belajar diharapkan tujuan pendidikan dapat tercapai berupa terjadinya perubahan tingkah laku dalam diri siswa, selain itu juga menjadi harapan semua pihak agar setiap siswa dapat memperoleh hasil belajar yang sebaik-baiknya sesuai dengan kemampuan masing-masing. Proses pembelajaran dapat dilaksanakan karena adanya tujuan yang hendak dicapai. Akan tetapi banyak guru gagal dalam melaksanakan proses pembelajaran, seperti banyaknya siswa yang tidak dapat mencapai tujuan yang diharapkan (Ananda \& Fadhilaturrahmi, 2018).

Pendidikan dan pengajaran adalah sebuah proses yang sadar tujuan. Sedangkan tujuan dapat berarti sebagai suatu usaha untuk memberikan rumusan hasil yang diinginkan siswa sesudah memperoleh pengalaman belajar. Tercapai atau tidak sebuah tujuan pengajaran salah satunya dapat terlihat dari prestasi belajar siswa yang telah diraih. Dengan prestasi yang tinggi, para siswa berindikasi mempunyai pengetahuan yang baik. Salah satu faktor yang mempengaruhi prestasi siswa adalah motivasi. Dengan adanya motivasi, siswa akan belajar lebih keras, ulet, tekun serta berkonsentrasi penuh dalam proses pembelajaran. Dorongan motivasi dalam belajar merupakan salah satu hal yang perlu ditingkatkan dalam upaya pembelajaran di sekolah (Hamdu \& Agustina, 2017). Dorongan tersebut berada dalam diri seseorang yang menggerakkan untuk melakukan sesuatu yang sesuai dengan dorongan dalam dirinya. Menurut Maslow (dalam Rini Kristiantari, 2015) sebagai aliran tokoh humanisme, kebutuhan manusia secara hirarki laten dalam manusia. Kebutuhan tersebut mencakup kebutuhan fisiologis (sandang pangan), kebutuhan rasa aman (bebas rasa bahaya), kebutuhan kasih sayang, kebutuhan dihargai dan dihormati, serta kebutuhan aktualisasi diri.

Motivasi belajar mempunyai peranan tersendiri dalam proses mencapai keberhasilan belajar di sekolah. Motivasi belajar perlu ditingkatkan dan dipelihara sehingga proses pembelajaran dapat berjalan lancar dan tujuan pembelajaran dapat tercapai seperti yang diharapkan. Tingginya motivasi siswa dalam belajar cenderung berpengaruh pada keaktifan siswa terlibat dalam proses pembelajaran. Begitu juga dengan siswa yang berhasil dalam belajar akan memiliki motivasi yang tinggi untuk terus belajar. Kesadaran guru sangat dibutuhkan ketika setiap siswa dalam suatu kelas memiliki kemauan dan minat yang berbeda-beda terhadap proses pembelajaran, bahkan ada juga siswa yang kehilangan 
minat dalam belajar. Oleh karena itu, maka guru harus mampu mendorong dan membangkitkan semangat siswa untuk dapat mengikuti proses pembelajaran yang sedang berlangsung.

Namun pada kenyataannya, banyak guru yang tidak mempedulikan begitu pentingnya pemberian motivasi belajar kepada siswa selama proses pembelajaran. Sehingga siswa cendrung tidak fokus dan sering bosan dalam mengikuti proses kegiatan belajar mengajar. Padahal motivasi belajar memiliki peran yang sangat penting. Motivasi belajar berpengaruh terhadap meningkatnya hasil belajar peserta didik. Hal tersebut sesuai dengan hasil penelitian yang menyatakan bahwa terdapat hubungan positif antara motivasi belajar dengan prestasi belajar. Motivasi belajar yang baik akan berdampak pada prestasi yang tinggi. Sebaliknya, apabila siswa tidak memiliki motivasi belajar yang baik, maka akan berdampak pada prestasi yang belum sesuai dengan harapan (Wijayani, 2017).

Berdasarkan observasi dan wawancara yang dilakukan peneliti di SDN 016 Kopah pada siswa kelas II, peneliti menemukan permasalahan yang signifikan yaitu kurangnya motivasi belajar yang di berikan oleh guru kepada siswa. Sedangkan Motivasi didalam proses pembelajaran sangat penting didapatkan oleh siswa, karena motivasi sangat berpengaruh terhadap hasil belajar yang didapat oleh siswa. Salah satu contoh siswa yang kurang motivasi dari guru, siswa akan terlihat malas dalam mengerjakan tugas dan akan kebiasaan mencontek. pada saat mengerjakan tugas yang diberikan oleh guru. Permasalahan yang terjadi di kelas II SDN 016 Desa Kopah Dalam hal motivasi belajar masih terkesan rendah dapat dilihat dari hasil belajar siswa, penyebab dari permasalahan ini antara lain disebabkan karena kurangnya motivasi yang didapatkan oleh siswa, baik motivasi intrinsik maupun motivasi ekstrinsik dan juga. Kurang maksimalnya komunikasi antara guru dan orang tua siswa yang menyebabkan hubungan kerjasama yang kurang maksimal dalam memotivasi belajar siswa baik di sekolah maupun di rumah. Terdapat beberapa permasalah yang terjadi di SDN 016 Desa Kopah sebagai berikut:

1. Kurangnya motivasi dari dalam diri siswa, hal ini disebabkan oleh kurangnya kesadaran siswa akan tanggung jawabnya sebagai seorang peserta didik dan siswa bahkan melalaikan tugas yang diberikan oleh guru di sekolah.

2. Kurang maksimalnya komunikasi antara orang tua dan guru didalam memotivasi belajar siswa, salah satu contohnya guru kurang mengontrol efektifitas jam belajar di sekolah sehingga siswa memiliki catatan absensi di kelas, dan hal ini sering kali tidak diketahui oleh orang tua siswa.

3. Kurang baiknya kondisi lingkungan siswa baik berupa keadaan alam, tempat tinggal, pergaulan sebaya dan kehidupan bermasyarakat yang berdampak negatif terhadap motivasi belajar siswa. 
Berdasarkan permasalahan di atas, peneliti tertarik ingin melakukan penelitian. Penelitian ingin mendeskripsikan bagaimana motivasi belajar siswa kelas II serta peneliti ingin mendeskripsikan bagaimana motivasi belajar instrinsik dan ekstrinsik siswa kelas II di SDN 016 Desa Kopah.

\section{METODE}

Dalam melakukan kajiannya, peneliti menggunakan penelitian kualitatif dengan pendekatan deskriptif. Karaktersitik dari penelitian deskriptif kualitatif adalah untuk mengeksplor suatu permasalahan atau fenomena sosial kemudian mengembangkan pemahaman yang lebih spesifik dari fenomena yang dikaji (Dafit \& Ramadan, 2020).

Penelitian ini mempunyai subjek guru kelas II serta siswa kelas II yang berjumlah 18 siswa di SDN 016 Desa Kopah. Teknik pengambilan subjek yaitu teknik purposive sampling. Teknik purposive sampling adalah cara pengambilan sampel data dengan pertimbangan tertentu. Pertimbangan tertentu tersebut, misalnya sampel yang diambil merupakan orang yang dianggap paling tahu tentang apa yang dibutuhkan oleh peneliti, atau mungkin dia sebagai penguasa/pimpinan sehingga lebih memudahkan peneliti dalam menjelajah obyek/situasi sosial yang dikaji (Sugiyono, 2017).

Selanjutnya peneliti mendapatkan data berdasarkan hasil observasi, wawancara, dan analisis dokumen. Peneliti melakukan wawancara dengan guru kelas II serta siswa kelas II di SDN 016 terkait motivasi belajar siswa kelas II SDN 016 Desa Kopah. Setelah peneliti melakukan kegiatan wawancara, peneliti melakukan kegiatan observasi. Kegiatan observasi dilakukan 5 kali selama proses pembelajaran. Peneliti mengikuti kegiatan belajar mengajar di dalam kelas II dari awal sampai akhir pembelajaran. Peneliti juga melakukan analisis dokumen seperti RPP, Silabus, Buku Guru dan Buku Siswa serta buku latihan siswa. Data yang telah terkumpul melalui teknik wawancara, observasi, serta analisis dokumen tersebut selanjutnya dianalisis. Dalam menganalisa data, peneliti menggunakan model Milles and Huberman dengan 3 tahapan yaitu reduksi data, penyajian data, dan penarikan kesimpulan.

\section{HASIL DAN PEMBAHASAN}

\section{Deskripsi Motivasi Belajar Siswa Kelas II SD 016 Desa Kopah}

Penelitian ini dilaksanakan di kelas II SDN 016 Desa Kopah, yang dilaksanakan selama 2 minggu. Selama proses penelitian, peneliti langsung terlibat dalam proses pembelajaran. Peneliti ikut masuk kedalam kelas dari awal sampai akhir pembelajaran selama 5 kali pertemuan. Selama penelitian, peneliti fokus terhadap siswa. Peneliti ingin melihat motivasi belajar siswa selama proses 
pembelajaran. Data yang peneliti kumpulkan adalah data mengenai bagaimana motivasi belajar siswa serta bagaimana motivasi belajar instrinsik serta motivasi ekstrinsik siswa kelas II SDN 016 Desa Kopah.

Berdasarkan hasil wawancara dengan guru, didapatkan data bahwa selama proses pembelajaran guru selalu memberikan motivasi belajar kepada siswa seperti memberikan pujian, dorongan, memberikan nasihat kepada siswa, dan melakukan kegiatan-kegiatan menarik seperti di dalam proses pembelajaran guru menggunakan media pembelajaran untuk memancing minat belajar peserta didik. Guru juga menyatakan bahwa motivasi belajar siswa kelas II sudah baik. Hanya saja ada beberapa siswa yang perlu selalu diberikan dorongan selalu agar selalu aktif di dalam proses pembelajaran.

Motivasi merupakan perubahan tenaga di dalam diri seseorang yang ditandai dengan dorongan yang berasal dari diri seseorang untuk mencapai tujuan. Dorongan serta reaksi-reaksi usaha yang disebabkan oleh adanya kebutuhan untuk berprestasi dalam hidup. Hal tersebut membuat individu mempunyai usaha, keinginan serta dorongan untuk mendapatkan hasil belajar yang tinggi (Maryam, 2016).

Dari hasil wawancara dengan peserta didik kelas II, diperoleh informasi bahwa di dalam proses pembelajaran, guru selalu memberikan pujian kepada siswa yang mau dan berani tampil di depan kelas serta berani memberikan jawaban atas pertanyaan yang diajukan guru. Peserta didik juga menyampaikan bahwa selama dalam proses pembelajaran guru terkadang memberikan nasihat kepada siswa yang malas untuk belajar. Hal tersebut sesuai dengan data hasil observasi yang didapatkan peneliti saat di lapangan. Ketika peneliti melakukan kegiatan observasi pada tanggal 23 Agustus 2021 peneliti melihat bahwa guru menggunakan media pembelajaran di dalam kelas. Tidak hanya itu, pada awal pembelajaran guru selalu memberikan nasihat kepada siswa untuk terus semangat dalam belajar dan tidak boleh banyak bermain. Pada saat pembelajaran, peneliti juga melihat guru memberikan sebuah pujian kepada siswa yang berani tampil di depan kelas untuk menjawab pertanyaan yang diajukan guru.

Berikut merupakan data-data siswa yang peneliti analisis mengenai motivasi belajar siswa pada saat proses pembelajaran di kelas II SDN 016 Desa Kopah yang berjumlah 13 siswa.

Tabel 1. Data-data siswa mengenai motivasi belajar siswa kelas II SDN 016 Desa Kopah

\begin{tabular}{lcl}
\hline No & Nama Siswa & Deskripsi Temuan \\
\hline 1. & ABK & Ketika proses pembelajaran, ABK terlihat aktif di dalam proses pembelajaran, hal \\
& tersebut dapat dilihat pada saat guru meminta salah satu siswa ke depan kelas \\
& untuk menjawab pertanyaan, kemudian ABK mengacungkan tangan dan ingin \\
& maju untuk menjawab pertanyaan. 5 kali peneliti melakukan pengamatan dan
\end{tabular}


peneliti melihat bahwa ABK sudah memiliki motivasi di dalam dirinya. Dan dapat diketahui bahwa ABK merupakan siswa juara 1 di kelas II.

2.

3.

4.

5.

6.

7.

8.

GAS
Pada saat proses pembelajaran, peneliti melihat bahwa AHS juga siswa yang aktif di kelas. Seperti pada saat peneliti melakukan wawancara, AHS menyatakan bahwa AHS memiliki keinginan untuk menjadi seorang guru. AHS juga aktif di dalam kelas seperti menjawab segala pertanyaan dari guru. Dan peneliti melihat bahwa pada saat AHS di puji oleh guru karena menjawab pertanyaan dengan benar, AHS semangkin rajin dan bersemangat di dalam proses pembelajaran.

AR Berbeda dengan ABK dan AHS. Siswa yang berinisal AR malah tampak diam dan tidak aktif di dalam proses pembelajaran. AR hanya mengerjakan tugas yang diberikan guru, pada saat tanya jawab AR terlihat sibuk membaca bukunya dan tidak memperhatikan guru di depan kelas. Dan terkadang AR tidur-tiduran di meja. Pada saat peneliti melakukan wawancara dengan AR, AR mengatakan bahwa AR malu untuk menjawab pertanyaan dan maju kedepan.

AR Pada saat proses pembelaaran, peneliti melihat siswa yang berinisial AR aktif di dalam proses pembelajaran. AR senang menjawab segala pertanyaan guru. Akan tetapi, AR suka mengggangu temannya. Pada saat dinasehati oleh guru, AR mendengarkan. Akan tetapi AR akan mengulangi kembali setelah guru mengabaikannya.

AN AN merupakan siswa yang hampir sama seperti AR. AN merupakan siswa pendiam di dalam kelas. Pada saat proses pembelajaran, guru meminta AN untuk tampil didepan kelas, akan tetapi AN tidak mau maju. Lalu kemudian guru memberikan semangat kepada AN dengan mengatakan bahwa "jangan takut salah, maju aja dulu". Guru memberikan nasihat kepada AN. Barulah AN mau maju kedepan kelas.

ERS Motivasi belajar siswa yang berinisial ERS, sudah dapat dikatakan baik. Hal ini dilihat dari hasil belajar siswa selama proses pembelajaran. Siswa terlihat aktif, dan mengerjakan semua tugas yang diberikan guru tepat pada waktunya. ERS juga saat diminta untuk mengerjakan tugas didepan kelas sangat bersemangat.

FA FA merupakan siswa yang pendiam. FA tidak banyak bicara dan bermain seperti teman lainnya. FA lebih suka mencoret-coret bukunya pada saat guru menjelaskan. Guru selalu memberikan motivasi dan nasihat kepada FA agar jangan suka mencoret-coret buku akan tetapi FA tidak mendengarkan.

GAS merupakan siswa yang tidak jauh berbeda seperti FA, GAS lebih suka diam dan memperhatikan temannya. Pada saat guru bertanya GAS hanya tersenyum dan saat diminta kedepan untuk mengerjakan tugas GAS baru akan maju kedepan kelas, jika tidak diminta maka GAS tidak akan maju kedepan kelas tidak seperti siswa lainnya yang berebutan ingin maju kedepan kelas. 
9. LAA

10. $\mathrm{R}$

11. SG

12. $\mathrm{MG}$

13. $\mathrm{HN}$
LAA merupakan siswa yang aktif. LAA suka bertanya kepada guru, dan pada saat guru meminta siswa maju kedepan kelas LAA akan lebih dulu maju kedepan kelas. Selain itu LAA juga selalu mengerjakan tugas tepat waktu.

$\mathrm{R}$ merupakan siswa yang aktif di dalam kelas. Numun R lebih banyak bermain dibandingkan belajar. Selain itu R juga suka menggangu temannya. Akan tetapi $\mathrm{R}$ siswa yang rajin dalam mengerjakan tugas. $\mathrm{R}$ juga memiliki ciata-cita untuk menjadi seorang dokter.

SG merupakan siswa yang aktif di dalam proses pembelajaran. SG juga paling semangat jika disuruh untuk maju kedepan kelas, selain itu SG juga rajin mengumpulkan tugas. SG juga memiliki cita-cit untuk menjadi dokter.

Pada saat penelitian, MG merupakan siswa yang sangat rajin menulis. Selama proses pembelajaran MG selalu menulis. Akan tetapi, MG jarang memperhatikan guru di dalam kelas. Guru selalu memberikan nasihat kepada MG untuk selalu fokus di dalam belajar dan memperhatikan siswa.

Selama proses pembelajaran, HN merupakan siswa yang aktif di dalam proses pembelajaran. HN juga senang bertanya dan menjawab pertanyaan dari guru. HN selalu mengumpulkan tugas tepat waktu. Tidak hanya itu, HN juga senang membaca guru selalu memberikan motivasi kepada $\mathrm{HN}$ agar selalu rajin membaca agar HN memiliki wawasan yang lebih luas.

\section{Deskripsi Data Penelitian Motivasi Instrinsik Siswa Kelas II}

Motivasi instrinsik merupakan suatu pendorong kerja yang bersumber dari dalam diri pekerja sebagai individu, berupa kesadaran mengenai pentingnya pekerjaan yang dilaksanakan (Maulana, 2015). Pada saat peneliti melakukan penelitian di SDN 016 Desa Kopah, peneliti melihat bahwa ada beberapa siswa yang sudah memiliki motivasi instrinsik. Salah satunya adalah siswa yang berinisial ABK. Peneliti melihat bahwa ABK sudah memiliki motivasi di dalam dirinya. Karena tanpa adanya pujian atau penghargaan serta dorongan yang diberikan guru $\mathrm{ABK}$ langsung maju kedepan kelas serta menjawab pertanyaan guru.

Hal tersebut dibenarkan oleh guru kelas II yang menyatakan bahwa dari seluruh siswa kelas II yang sudah terlihat bahwa memiliki motivasi belajar dari dalam dirinya adalah $\mathrm{ABK}$ dan $\mathrm{ABK}$ merupakan siswa juara kelas. Pada saat peneliti melakukan wawancara, ABK menyatakan bahwa AB sudah terbiasa diberikan dorongan dan motivasi oleh orang tua. ABK selalu diberikan nasihat oleh orang tua. Jika ABK ingin menjadi anak yang sukses maka ABK harus rajin dalam belajar. Tidak hanya ABK, siswa yang berinisial AHS juga merupakan siswa yang sudah terlihat bahwa memiliki motivasi instrinsik di dalam dirinya, karena pada saat peneliti melakukan wawancara, pada saat peneliti bertanya apakah AHS memiliki cita-cita, kemudian AHS menjawab bahwa AHS memiliki 
cita-cita untuk menjadi seorang guru. Faktor- faktor motivasi instrinsik siswa kelas II SDN 016 Desa Kopah sebagai berikut:

a. Adanya hasrat dan keinginan berhasil.

Siswa kelas II SDN 016 Desa Kopah, hampir semua siswa memiliki hasrat untuk belajar dan berhasil. Hal ini terbukti pada saat proses pembelajaran semua siswa terlihat tenang dan aktif di dalam proses pembelajaran.

b. Adanya dorongan dan kebutuhan dalam belajar

Di dalam proses pembelajaran, peneliti menemukan informasi bahwa selama proses pembelajaran guru terus memberikan dorongan kepada siswa untuk selalu rajin belajar dan jangan banyak bermain, sehingga hampir semua siswa aktif di dalam proses pembelajaran.

c. Adanya harapan dan cita-cita masa depan

Dari beberapa siswa kelas II SDN 016 Desa Kopah yang berhasil peneliti wawancarai, setiap siswa memiliki harapan dan cita-cita. Seperti salah satu siswa yang berinisial AHS. AHS menyatakan bahwa memiliki cita-cita untuk menjadi seorang guru. Hal ini menandakan bahwa AHS sudah memiliki motivasi di dalam dirinya.

\section{d. Adanya penghargaan dalam belajar}

Dari hasil penelitian, peneliti melihat bahwa guru memberikan penghargaan kepada siswa yang berani dan aktif selama proses pembelajaran. Seperti siswa yang berani maju kedepan kelas guru menyatakan bahwa guru akan memberikan nilai kepada siswa yang berani maju kedepan kelas, sehingga siswa termotivasi untuk maju dan menjawab pertanyaan dari guru.

\section{Deskripsi Data Penelitian mengenai Motivasi Ekstrinsik Siswa Kelas II}

Motivasi ekstrinsik disebut demikian karena tujuan utama individu melaksanakan kegiatan adalah untuk mendapatkan tujuan yang berada di luar aktivitas belajar itu sendiri, atau tujuan tersebut tidak terlibat di dalam aktivitas belajar. Motivasi ekstrinsik adalah segala sesuatu yang didapatkan melalui pengamatan sendiri, ataupun melalui saran, anjuran, atau dorongan dari oranglain (Ena \& Djami, 2021).

Di SDN 016 Desa Kopah, ditemukan informasi bahwa ada beberapa siswa yang harus selalu diberikan dorongan agar aktif dan berani maju kedepan kelas. Hal tersebut sama dengan pernyataan guru yang menyampaikan bahwa masih ada beberapa siswa yang kurang aktiif di dalam kelas, sehingga guru selalu memberikan dorongan kepada siswa tersebut. Seperti sekali-sekali guru meminta siswa untuk membantu guru maju ke depan kelas untuk menghapus papan tulis. Tujuan guru 
adalah agar siswa terbiasa maju kedepan kelas. Tidak hanya itu, guru juga menyatakan guru selalu menunjuk siswa tersebut dan memberikan kesempatan untuk menyampaikan pendapatnya serta guru juga selalu memberikan pujia seperti tepuk tangan ketika siswa tersebut berani tampil di depan kelas.

Hal ini sesuai dengan pernyataan siswa yang menyatakan bahwa malu untuk maju kedepan kelas. Sehingga siswa tidak berani untuk menjawab pertanyaan apalagi mengerjakan didepan kelas. Ketika peneliti melakukan kegiatan observasi, peneliti melihat bahwa siswa yang berinisial AN selalu diberikan kesempatan oleh guru untuk mengeluarkan pendapatnya. Tidak hanya itu, guru juga memberikan pujian seperti tepuk tangan kepada siswa tersebut, sehingga siswa tersebut berani tampil di depan kelas.

Berdasarkan pernyataan di atas, maka dapat diambil kesimpulan bahwa terdapat beragam motivasi belajar siswa. Ada siswa yang mempunyai motivasi dengan kriteria instrinsik dan ada juga siswa yang mempunyai motivasi ekstrinsik. Faktor-faktor motivasi instrinsik siswa, yaitu 1) adanya hasrat dan keinginan berhasil, 2) adanya dorongan dan kebutuhan dalam belajar, 3) adanya harapan dan cita-cita masa depan, 4) adanya penghargaan dalam belajar.

Motivasi belajar merupakan keseluruhan tenaga penggerak di dalam diri siswa yang menjadikan kegiatan belajar terjamin keberlangsungannya serta memberikan arah pada pelaksanaan kegiatan belajar sehingga tujuan diharapka dapat tercapai. Dalam motivasi belajar, dorongan dijadikan sebagai kekuatan mental untuk melaksanakan kegiatan dalam rangka pemenuhan harapan seta dorongan dalam pencapaian tujuan (Manuhutu, 2015).

Di SDN 016 Desa Kopah, guru kelas II selalu memberikan motivasi kepada siswa selama proses pembelajaran. Motivasi yang diberikan guru merupakan dalam bentuk pujian, penghargaan, dorongan, dan kegiatan belajar yang menarik. Hal ini sesuai dengan pernyataan (Romas, 2020) mengatakan bahwa perbuatan yang disertai atau diikuti oleh akibat yang menyenangkan cenderung untuk dipertahankan atau diulang-ulang. Akibat yang menyenangkan tersebut bisa berupa pemberian pujian, atau biasa disebut sebagai ganjaran positif, serta dapat memberikan efek positif. Sebaliknya ganjaran negatif seperti hukuman akan merusak dan menurunkan harga diri seseorang.

Dilihat dari jenis-jenis motivasi yaitu motivasi instrinsik dan ekstrinsik motivasi belajar siswa kelas II di SDN 016 Desa Kopah beragam. Terdapat sisiwa yang sudah memiliki kriteria motivasi instrinsik dan masih ada siswa yang termasuk kriteria ekstrinsik. Siswa yang termasuk kedalam motivasi instrinsik adalah siswa yang berani tampil di depan kelas tanpa adanya dorongan dan paksaaan dari guru, siswa yang memiliki hasrat ingin belajar, siswa yang memiliki cita-cita. Hal ini sesuai dengan pendapat (Risqi et al., 2006) yang menyatakan bahwa motivasi instrinsik adalah motivasi yang mendorong seseorang untuk berprestasi yang bersumber dari dalam diri individu 
tersebut, yang lebih dikenal dengan faktor motivasional. Faktor-faktor motivasi siswa, yaitu 1) adanya hasrat dan keinginan berhasil, 2) adanya dorongan dan kebutuhan dalam belajar, 3) adanya harapan dan cita-cita masa depan, 4) adanya penghargaan dalam belajar.

Selain siswa yang sudah termasuk di dalam kriteria motivasi instrinsik, masih ada beberapa siswa yang termasuk kedalam motivasi ekstrinsik. Siswa yang masih diberikan dorongan dan pujian terlebih dahulu agar berani tampil di depan kelas. Hal ini sesuai dengan pengertian motivasi ekstrinsik. Motivasi ekstrinsik disebut demikian karena tujuan utama individu melaksanakan kegiatan adalah untuk mendapatkan tujuan yang berada di luar aktivitas belajar itu sendiri, atau tujuan tersebut tidak terlibat di dalam aktivitas belajar. Motivasi ekstrinsik adalah segala sesuatu yang didapatkan melalui pengamatan sendiri, ataupun melalui saran, anjuran atau dorongan dari oranglain (Ena \& Djami, 2021).

\section{KESIMPULAN}

Motivasi merupakan proses yang dapat memberikan semangat, arah, dan kegigihan perilaku. Hal ini berarti perilaku yang memperoleh motivasi adalah perilaku yang penuh energi, terarah, dan bertahan lama. Dalam pendidikan, hakikat seorang guru bertugas mencerdaskan bangsa dalam suatu bentuk dalam pendidikan formal. Namun, setiap usaha yang dilaksanakan pasti tidak akan terlepas dari faktor penghambat dalam mencapai tujuan yang diinginkan

Guru adalah faktor terbesar dalam menentukan keberhasilan proses belajar mengajar. Seorang guru tidak hanya mempunyai peran sebagai fasilitator dan mediator, namun juga dituntut untuk bisa berperan sebagai motivator yang dapat meningkatkan semangat dan dorongan kepada siswa dalam belajar dengan menggunakan berbagai keterampilan mengajar yang dalam pembentukan kompetensi dasar siswa yang lebih baik dari segi pengetahuan, keterampilan, maupun sikapnya.

Berdasarkan hasil penelitian di kelas II SDN 016 Desa Kopah, diperoleh informasi bahwa di dalam proses pembelajaran guru selalu menumbuhkan motivasi belajar siswa. Guru selalu memberikan motivasi belajar kepada siswa seperti memberikan pujian, dorongan, memberikan nasihat kepada siswa, dan melakukan kegiatan-kegiatan menarik seperti di dalam proses pembelajaran guru menggunakan media pembelajaran untuk memancing minat belajar peserta didik.

Motivasi terbagi menjadi dua, yaitu motivasi instrinsik dan motivasi ekstrinsik. Di SDN 016 Desa Kopah, terdapat siswa yang sudah memiliki motivasi instrinsik. Hal tersebut ditandai pada saat proses pembelajaran, siswa memiliki hasrat untuk belajar, aktif di dalam proses pembelajaran, memiliki harapan dan cita-cita, adanya penghargaan dalam belajar. Selain itu masih terdapat siswa yang termasuk kedalam motivasi ekstrinsik. 


\section{DAFTAR PUSTAKA}

Ananda, R., \& Fadhilaturrahmi, F. (2018). Analisis Kemampuan Guru Sekolah Dasar Dalam Implementasi Pembelajaran Tematik Di Sd. Jurnal Basicedu, 2(2), 11-21. https://doi.org/10.31004/basicedu.v2i2.42

Dafit, F., \& Ramadan, Z. H. (2020). Pelaksanaan Program Gerakan Literasi Sekolah (GLS) di Sekolah Dasar. Jurnal Basicedu, 4(4), 1429-1437. https://doi.org/10.31004/basicedu.v4i4.585

Ena, Z., \& Djami, S. H. (2021). Peranan Motivasi Intrinsik Dan Motivasi Ekstrinsik Terhadap Minat Personel Bhabinkamtibmas Polres Kupang Kota. Among Makarti, 13(2), 68-77. https://doi.org/10.52353/ama.v13i2.198

Hamdu, G., \& Agustina, L. (2017). Motivasi1.Pdf. Pengaruh Motivasi Belajar Siswa Terhadap Pestasi Belajar Ipa Di Sekolah Dasar, 12(1), 90-96.

Literate, S., \& Indonesia, J. I. (2020). View metadata, citation and similar papers at core.ac.uk. 2(1994), 274-282.

Manuhutu, S. (2015). Analisis Motivasi Belajar Internal Siswa Program Akselerasi Kelas Viii Smp Negeri 6 Ambon. PROMOSI (Jurnal Pendidikan Ekonomi), 3(1), 104-115. https://doi.org/10.24127/ja.v3i1.147

Maryam, M. (2016). Pengaruh Motivasi dalam Pembelajaran. Lantanida Journal, 4(2), 88-97. https://jurnal.ar-

raniry.ac.id/index.php/lantanida/article/download/1881/1402\%0Ahttps://media.neliti.com/me dia/publications/287678-pengaruh-motivasi-dalam-pembelajaran-dc0dd462.pdf

Maulana, F. (2015). Pengaruh Motivasi Intrinsik, Motivasi Ekstrinsik Dan Komitmen Organsasi Terhadap Kinerja Karyawan Pada Bank Btn Kantor Cabang Malang. Jurnal Administrasi Bisnis S1 Universitas Brawijaya, 22(1), 85893.

Nugroho, G. (2020). Analisis motivasi belajar siswa pada pembelajaran IPA di SDN 16/ii Sepunggur. Integrated Science Education Journal, 1(2), 67-71. https://doi.org/10.37251/isej.v1i2.67

Rini Kristiantari, M. (2015). Analisis Kesiapan Guru Sekolah Dasar dalam Mengimplementasikan Pembelajaran Tematik Integratif Menyongsong Kurikulum 2013. JPI (Jurnal Pendidikan Indonesia), 3(2), 460-470. https://doi.org/10.23887/jpi-undiksha.v3i2.4462 
Risqi, H. B., Saleh, C., \& Prihatini, D. (2006). Pengaruh motivasi intrinsik dan motivasi ekstrinsik terhadap kinerja melalui perilaku kerja karyawan honorer Hotel dan Pemandian Kebonagung Jember. Artikel Ilmiah Mahasiswa 2016. http://repository.unej.ac.id/bitstream/handle/123456789/78345/HIDAYAH B BAR RISQI.pdf?sequence $=1 \&$ isAllowed $=\mathrm{y}$

Sugiyono. (2017). Metode Penelitian Kuantitatif Kualitatif dan R\&D. Alfabeta.

Wijayani, I., Haenilah, E. Y., \& Sugiman, S. (2017). Hubungan Motivasi Belajar dengan Prestasi Belajar Siswa Kelas V. Pedagogi: Jurnal Pendidikan Dasar, 5(16), 3-7. http://jurnal.fkip.unila.ac.id/index.php/pgsd/article/view/13942 